\title{
EFFECT OF POLYETHYLENE MULCHES ON SOIL TEMPERATURE AND TOMATO YIELD IN PLASTIC GREENHOUSE ${ }^{1}$
}

\author{
N.A. STRECK²; F.M. SCHNEIDER²; G.A. BURIOL'; A.B. HELDWEIN ${ }^{2}$ \\ ${ }^{2}$ Depto. de Fitotecnia -CCR/UFSM, CEP: $97119-900$ - Santa Maria, RS.
}

\begin{abstract}
The effect of soil mulching with transparent, black, white, and co-extruded white-on-black polyethylene sheets on soil temperature and tomato yield was evaluated in the Subtropical Central Region of the Rio Grande do Sul State, Brazil. The experiment was carried out from August 21, 1994 to December 2, 1994 in a 10m x 25m nonheated plastic greenhouse located at the county of Santa Maria. Highest soil temperatures were obtained under transparent mulch. Maximum amplitude of soil temperature waves was smaller under opaque mulches. Tomato yield was not significantly affected by mulch treatments, however, a tendency of greater yield was observed for opaque mulches as compared to transparent mulch. Among opaque mulches, the highest yield was obtained from white mulches.
\end{abstract}

Key Words: mulching, soil temperature, tomato, plastic greehouse

\section{EFEITO DA COBERTURA DE POLIETILENO SOBRE A TEMPERATURA DO SOLO E PRODUTIVIDADE DO TOMATEIRO EM ESTUFA PLASTICA}

\begin{abstract}
RESUMO: Este experinento foi conduzido para avaliar o efeito da cobertura do solo com polietileno transparente, preto, branco e co-extruzado branco-preto sobre a temperatura do solo e produtividade do tomateim no interior de uma estufa plástica, em Santa Maria, Rio Grande do Sul, Brasil. O periodo experimental foi de 21 de agosto a 02 de dezembro de 1994. Observou-se que a temperatura múxima e métia dí́nia do solo foi maior sob polietileno transparente. A amplitude máxima da onda diária de temperatura do solo foi menor nos materiais opacos em relação ao transparente. Não houve diferença estatística na produtividade do tomateiro entre os tratamentos, mas a produtividade média foi maior com plásticos opacos do que com o plástico transparente. Entre os plásticos opacos, a maior produtividade foi obtida nos plásticos brancos, que refletem maior fração da radiação solar global incidente do que o plástico preto. Descritores: cobertura, temperatura do solo, tomateiro, estufa plastica
\end{abstract}

\section{INTRODUCTION}

Polyethylene (PE) mulches have induced large increases in growth and yields for a variety of crops, including tomato (EMMERT, 1957; TAKATORI et al., 1964; VANDENBERG \& TIESSEN, 1972; MULLINS et al., 1992; LAMONT Jr., 1993). These growth and yield increases have been attributed to changes in soil and air temperature near the cover, soil water balance, and nutrient availability compared to unmulched soil (CLARKSON \& FRAZIER, 1957; CLARKSON,
1960; BRUNINI et al., 1976; HAYNES, 1987). Less soil compaction and hence improved aeration under mulched soil have also contributed to increased plant growth (EKERN, 1967; LAMONT Jr., 1993).

Soil temperature can be differentially affected by the type of PE mulch with temperatures generally following the order: transparent mulch > black mulch $>$ white mulch (HAYNES, 1987). This is caused primarily through changes in the components of the radiation balance, due to the effect of mulches on albedo, sensible heat flux, latent heat flux, and soil heat flux (ROSENBERG, 1974;

\footnotetext{
1 Research supported by FAPERGS (Fundação de Amparo à Pesquisa do Estado do Rio Grande do Sul) and PETROQUfMICA TRIUNFO S.A.
} 
LIAKATAS et al., 1986). Transparent materials present high transmissivity to solar radiation and thus they are more effective in increasing soil temperature in comparison to the opaque materials, which higly reflect or absorb solar radiation (ROSENBERG, 1974).

The effects of various mulches on soil microclimate recently have been reviewed by STRECK et al. (1994). In this review the authors demonstrated that opaque mulches (black, white and colored plastics, paper, petroleum, bitumen, and straw) decrease the soil heat flux and the daily amplitude of the soil temperature. Transparent and translucent mulches promote a relatively large net radiation at the soil surface, increase soil heat flux and, as a consequence, the minimum and maximum soil temperature are increased.

LAMONT Jr. (1993) reviewed others aspects of plastic mulch as especifications, importance of color, and its advantages and disavantages. The color of a mulch determines its energy-radiating behavior and its influence on the microclimate around the plant. Black, transparent, and white mulches predominate in the commercial vegetable production today over the world (LAMONT Jr, 1993). White mulch has been replaced largely by a co-extruded white-on-black.

Black mulch predominate in vegetable production systems in Southern Brazil. Transparent mulches are most used in coller regions to promote earlier yields (FARIAS-LARIOS et al., 1994; LAMONT Jr., 1993; TABER, 1993; STRECK et al., 1994). White, white-on-black, and aluminized materials constitute the family of reflective mulches. These mulches reflect back into the plant canopy most of the incoming solar radiation, and consequently, are more effective in increasing crop yields (PENDLETON et al., 1966; LAMONT Jr., 1993; STRECK et al., 1994; FARIAS-LARIOS et al., 1994).

Since the middle 1980s the use of plastic materials to protect horticultural crops in tunnels and greenhouses is increasing in Southern Brazil. The atmosphere of plastic tunnels and greenhouses presents high values of relative humidity. Soil mulching reduce soil evaporation and an improve in the aerial environment around the plants is expected by its use. Tomato crop represents up to $80 \%$ of the protected area in Rio Grande do Sul State because its highest value.

The purpose of the current study was to determine the effects of different polyethylene mulches on soil temperature and tomato yield inside a plastic greenhouse.

\section{MATERIAL AND METHODS}

The experiment was carried out in a $10 \mathrm{~m} x$ $25 \mathrm{~m}$ nonheated greenhouse covered with low density transparent polyethylene with $100 \mu \mathrm{m}$ thickness, located at the Experimental Field of the Crop Production Department of the Federal University of Santa Maria, RS, Brazil (29 $29^{\circ}$ 'S'S latitude, $53^{\circ} 48^{\prime} \mathrm{W}$ longitude, and $95 \mathrm{~m}$ altitude). The texture of the greenhouse soil is loam, with $36 \%$ sand, $38 \%$ silt, and $26 \%$ clay.

Individual plots of $5.2 \mathrm{~m} \times 2 \mathrm{~m}$ were arranged in a randomized complete block design with four replications. Soil mulching treatments were: opaque black PE (30 $\mu \mathrm{m}$ tickness), transparent PE $(50 \mu \mathrm{m}$ thickness), opaque white PE $(50 \mu \mathrm{m})$, and a co-extruded white-on-black PE (100 $\mu$ m thickness). The white side of the co-extruded white-on-black sheet was set up and consequently, it operated as a opaque white mulch. The mulches were applied on August 21, 1994. Organic fertilizer (6 kg of bovine compost/linear meter) was used in the plant row at $20 \mathrm{~cm}$ depth. No chemical fertilizer was applied.

"Monte Carlo" tomato, an indeterminated growth variety, was sown on July 15, 1994. Seedlings of 4-leaf were planted on August 22, 1994, using $0.40 \mathrm{~m} \times 1.00 \mathrm{~m}$ plant spacing. Each plot had two rows with tomato plants (13 plants/row and 26 plants/plot). Plants were irrigated by drip irrigation lines under the mulch. Water was applied through the irrigation lines as needed to keep tensiometer readings below $80 \mathrm{kPa}$. Two tensiometers placed at $10 \mathrm{~cm}$ depth whithin plant row monitored the soil moisture. The most common recommended agronomic pratices for tomato in plastic greenhouse were followed throughout the investigation. Tomato plants were pruned at $1.80 \mathrm{~m}$ height (6-7 clusters).

Soil temperature was measured throughout the plant growth period using mercury-in-glass geothermometers in one plot of each mulching treatment. Geothermometers were buried at $2 \mathrm{~cm}$, $5 \mathrm{~cm}, 10 \mathrm{~cm}$, and $20 \mathrm{~cm}$ depths in the mulched plots within the rows of tomato plants.

Daily measurements of soil temperature were taken at $9 \mathrm{~h} 00 \mathrm{~min}, 15 \mathrm{~h} 30 \mathrm{~min}, 16 \mathrm{~h} 00 \mathrm{~min}, 17 \mathrm{~h} 30 \mathrm{~min}$, and $21 \mathrm{~h} 00 \mathrm{~min}$, local standard time (LST). At Santa Maria, RS, the daily minimum soil temperature at $20 \mathrm{~cm}$ depth occur near to $9 \mathrm{~h}$ and the daily maximum soil temperature at $2 \mathrm{~cm}, 5 \mathrm{~cm}, 10 \mathrm{~cm}$, and 
$20 \mathrm{~cm}$ depths, occur near the afternoon measurements above cited, respectively (SCHNEIDER, 1979). Thus, the daily mean soil temperature at $20 \mathrm{~cm}$ depth $\left(\mathrm{Tm}_{20}\right)$ was calculated by:

$$
T m_{20}=\left(T_{200 m o n}+T_{20 \mathrm{~cm} 21 \mathrm{~b}}\right) / 2
$$

Where $\mathbf{T}_{20 \mathrm{n}}$ and $\mathbf{T}_{20 \mathrm{cos} / \mathrm{l}}$ are the minimum and maximum soil temperature at $20 \mathrm{~cm}$ depth, respectively.

According to DEClCO (1974) and SCHNEIDER (1979) if the mean soil temperature at a given depth is known, it can be assumed as being the mean temperature of the soil profile (T). Assuming that the daily wave of soil temperature follow a sinuosidal model, regardless of the depth, the maximum amplitude of the soil temperature wave (T) at each depth (i) can be estimated by:

$$
T_{.}=\operatorname{Tmax}_{1}-\operatorname{Tm}_{20}
$$

Equations (1) and (2) were used to estimate the mean temperature of soil and the maximum amplitude of each soil depth under the mulched plots.
Twelve tomato plants per treatment were tagged and the duration of planting-flowering and planting-ripening sub-periods were recorded in the lower cluster. Flowering date (anthesis) was considered when the first flower of the lower cluster was completely opened. Ripening date was assumed as the day when the first fruit of the plant was red dyed. Fruits were harvested once a week from October 27, 1994 to December 02, 1994. The yield parameters evaluated were number and weight of marketable and nonmarketable harvested fruits. Nonmarketable fruits were those with defects and/ or disorders. Early yield was considered as the total weight of marketable fruits of the first three harvests. Crop yield was determined on basis of area per plot $\left(10.5 \mathrm{~m}^{2}\right)$. Data were subjected to analysis of variance and differences among means were distinguished using the Duncan's test.

\section{RESULTS AND DISCUSSION}

The highest soil temperature occured under transparent PE followed by white, black, and co-extruded white-on-black PE, regardless the depth (TABLE 1). In general, this effect was more evident during the early crop season when tomato plants

TABLE 1. Average values of daily maximun temperature $\left({ }^{\circ} \mathrm{C}\right)$ of mulched soil of the plastic greenhouse throughout the experimental period. Santa Maria, RS, Brazil, 1994.

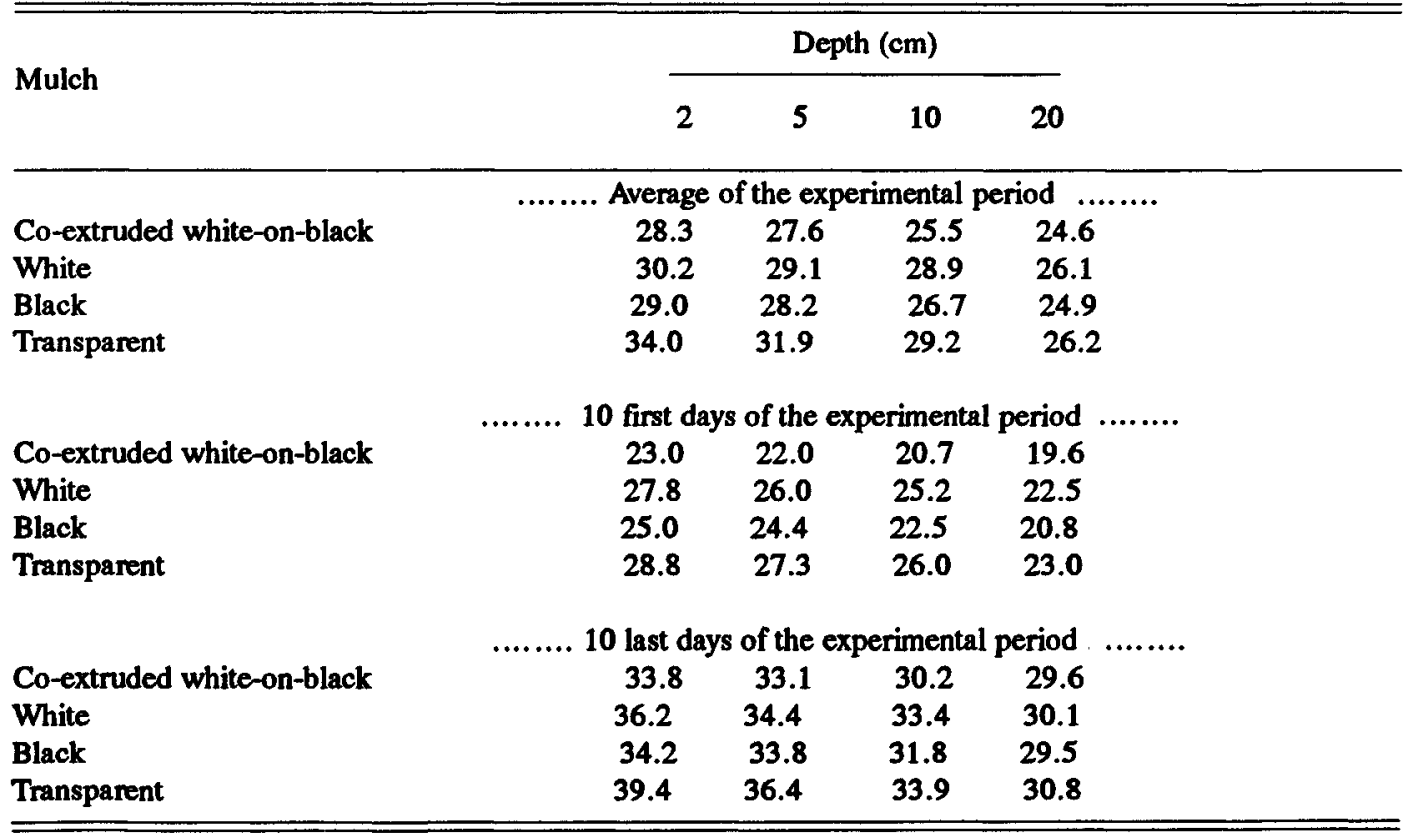


shaded less the soil surface. Average values of mean soil temperature followed the same trend (TABLE 2).

Transparent mulches are more effective in increasing soil temperature due a greater net radiation under the mulch compared to opaque mulches (ROSENBERG, 1974; LIAKATAS et al., 1986; STRECK et al. , 1994). Consequently, the soil heat flux is substantially greater under transparent mulch. LIAKATAS et al. (1986) reported that the maximum soil heat flux was up to $67 \%$ higher under transparent mulch in comparison to the black mulch. White PE used in this study trended to increase maximum temperature compared to the other opaque mulches (black and co-extruded white-on-black PE). This increase probably occured due to the white PE is not completly opaque. It is expected that white and co-extruded white-on-black PE have a similar effect on soil temperature.

The maximum amplitude of soil temperature was different in the mulch treatments (TABLE 2). Small amplitude was achieved in opaque mulches. This effect was greater on clear days, but it remained on cloudy days. Similar results were reported by
LIAKATAS et al. (1986). The amplitude of the soil temperature wave decreased with depth, regardless the mulch. This behavior follows the classical theory of soil heat flux, where temperature wave is dampened when the depth increases.

The effect of mulching materials on soil temperature obtained in this study are in agreement with those reported by others researchers (ROSENBERG, 1974; LIAKATAS et al., 1986; HAYNES, 1987; STRECK et al., 1994).

Tomato plants began flowering and ripening at the same time in the mulch treatments (TABLE 3). Small differences were observed in ripening between white and black mulch ( 5 days). Parameters of tomato yield were not significantly affected by mulch treatments. However, it can be observed that highest tomato yields were obtained in opaque mulches. Similar results were reported by SALMAN et al. (1990) with cucumber and cantaloupe inside a plastic greenhouse.

As indicated previously, transparent PE raised soil temperature compared to the opaque PE. According to REY \& COSTES (1965) the optimal range of soil temperature for tomato root growing is

TABLE 2. Values of mean temperature $(T)$ and maximum amplitude $(T)$ of temperature $\left({ }^{\circ} \mathrm{C}\right)$ of mulched soil of the plastic greenhouse. Santa Maria, RS, Brazil, 1994.

\begin{tabular}{|c|c|c|c|c|c|c|c|c|}
\hline \multirow{2}{*}{$\begin{array}{l}\text { Depth } \\
\text { (cm) }\end{array}$} & \multicolumn{2}{|c|}{ Co-extruded White-on-black } & \multicolumn{2}{|c|}{ White } & \multicolumn{2}{|c|}{ Black } & \multicolumn{2}{|c|}{ Transparent } \\
\hline & $\mathbf{T}$ & $T_{0}$ & $\mathrm{~T}$ & $T_{0}$ & $\mathbf{T}$ & $T_{0}$ & $\mathbf{T}$ & $T_{0}$ \\
\hline & \multicolumn{8}{|c|}{........ Average of the experimental period ......... } \\
\hline 2 & 23.9 & 4.4 & 25.1 & 5.2 & 24.2 & 4.6 & 24.9 & 9.1 \\
\hline 5 & & 3.7 & & 4.0 & & 4.1 & & 7.0 \\
\hline 10 & & 1.6 & & 3.8 & & 2.6 & & 4.4 \\
\hline \multirow[t]{2}{*}{20} & & 0.7 & & 1.0 & & 0.9 & & 1.4 \\
\hline & \multicolumn{8}{|c|}{$\ldots \ldots \ldots 5$ clear days $(n / N>0.9) \ldots \ldots}$. \\
\hline 2 & 24.1 & 5.7 & 25.4 & 6.3 & 24.4 & 5.5 & 25.7 & 11.6 \\
\hline 5 & & 4.9 & & 5.4 & & 5.1 & & 9.2 \\
\hline 10 & & 2.1 & & 4.2 & & 3.1 & & 5.5 \\
\hline \multirow[t]{2}{*}{20} & & 1.1 & & 1.3 & & 1.1 & & 1.9 \\
\hline & \multicolumn{8}{|c|}{$\ldots \ldots . .5$ cloudy days $(n / N<0.1) \ldots \ldots \ldots$} \\
\hline 2 & 22.6 & 1.7 & 23.8 & 2.2 & 23.0 & 2.0 & 23.3 & 3.9 \\
\hline 5 & & 1.5 & & 1.5 & & 1.7 & & 3.5 \\
\hline 10 & & 0.8 & & 1.0 & & 0.7 & & 1.7 \\
\hline 20 & & 0.3 & & 0.3 & & 0.2 & & 0.3 \\
\hline
\end{tabular}

$\mathrm{n}=$ sunshine duration (hours/day)

$\mathrm{N}=$ day length (hours/day) 
$20-30^{\circ} \mathrm{C}$, while temperatures of $38^{\circ} \mathrm{C}$ or more decrease water absorption and reduce plant growth. Soil temperature at $2 \mathrm{~cm}$ depth achieved absolute values of up to $42.2,40.8,38.0$, and $37.0^{\circ} \mathrm{C}$ under transparent, white, black, and co-extruded white-on-black $\mathrm{PE}$, respectively, during the tomato growing period. Observed maximum temperature at $2 \mathrm{~cm}$ depth exceeded $38^{\circ} \mathrm{C}$ in 23,2 , and 1 days under transparent, white, and black PE, respectively. Thus, soil temperature was probably harmfull to the tomato plants in the transparent mulch. High soil temperature enhances vegetative growing and decreases tomato yield (REY \& COSTES, 1965).

Several papers have demonstrated that transparent mulches increase yield and improve crop growth of many field-grown vegetable crops compared to the opaque mulches (NABER, 1993; FARIAS-LARIOS et al., 1994). This increase have been reported especially in cold regions, where soil temperature is low and limitant for plant growth. Soil temperature of plastic greenhouses in Central Region of the Rio Grande do Sul State is not a limitant factor to the greater number of horticultural vegetable crops (SCHNEIDER et al., 1993). This can explain the lowest yield obtained with transparent PE mulch in this experiment. As a consequence of high temperature, the use of transparent $P E$ mulch probably also reduced plant survival compared to the opaque mulches (TABLE 4).

Other problem presented by transparent mulch is the weed growth. A new

TABLE 3. Effect of polyethylene mulches on duration of planting-flowering (P-F) and planting-ripening (P-R), early yield (EY), and marketable (MK) and nonmarketable (NMK) yield of tomato inside a plastic greenhouse. Santa Maria, RS, Brazil, 1994.

\begin{tabular}{|c|c|c|c|c|c|c|c|c|}
\hline \multirow{3}{*}{ Mulch } & \multirow{2}{*}{\multicolumn{2}{|c|}{ P-F P-1 }} & & \multirow{3}{*}{$\begin{array}{c}\text { EY } \\
\left(\mathrm{kg} / \mathrm{m}^{2}\right)\end{array}$} & \multicolumn{4}{|c|}{ Total Yield } \\
\hline & & & & & \multicolumn{2}{|c|}{ Fruit weight $\left(\mathrm{kg} / \mathrm{m}^{2}\right)$} & \multicolumn{2}{|c|}{ Fruit number $/ \mathrm{m}^{2}$} \\
\hline & \multicolumn{2}{|c|}{ days } & & & MK & NMK & MK & NMK \\
\hline Co-extruded white-on-Black & 27 & 75 & & $0.55 \mathrm{a}^{*}$ & $4.27 a$ & $0.55 \mathrm{a}$ & $25 \mathrm{a}$ & $7 a$ \\
\hline White & 27 & 73 & & $0.64 a$ & $4.01 a$ & $0.42 \mathrm{a}$ & $25 a$ & $5 a$ \\
\hline Black & 28 & 77 & & $0.40 \mathrm{a}$ & $3.81 \mathrm{a}$ & $0.42 \mathrm{a}$ & $23 a$ & $5 a$ \\
\hline Transparent & 28 & 75 & & $0.44 \mathrm{a}$ & $3.60 \mathrm{a}$ & $0.45 a$ & $21 a$ & $6 a$ \\
\hline C.V. (\%) & & & & 65.38 & 14.55 & 26.02 & 16.77 & 20.37 \\
\hline \multirow{2}{*}{\multicolumn{9}{|c|}{$\begin{array}{l}\text { Means in each column followed by the same letter are not significantly different by Duncan's Multiple Range } \\
\text { test }(P<0.05) \text {. } \\
\text { TABLE 4. Tomato plant survival sampled during the fruit harvest period in the soil mulch treatments of the } \\
\text { plastic greenhouse. Santa Maria, RS, Brazil. } 1994 \text {. }\end{array}$}} \\
\hline & & & & & & & & \\
\hline \multirow{3}{*}{ Mulch } & & & \multicolumn{4}{|c|}{ plant/plot } & & \\
\hline & & & \multicolumn{2}{|c|}{ 1st harvest } & \multicolumn{2}{|c|}{ 6th harvest } & & \\
\hline & & & number & $\%$ & number & $\%$ & & \\
\hline Co-extruded white-on-Black & & & 24 & 92 & 24 & 92 & & \\
\hline White & & & 25 & 96 & 24 & 92 & & \\
\hline Black & & & 25 & 96 & 25 & 96 & & \\
\hline Transparent & & & 20 & 77 & 20 & 77 & & \\
\hline
\end{tabular}

\% over the initial plant number/plot (26pl/plot). 
wavelength-selective plastic mulch has been developed that combine the properties of the black and the transparent mulch (TABER, 1993; LAMONT Jr, 1993). This new films transmit solar infrared radiation that warms the soil but blocks a portion of the photosynthetic radiation, thus limiting weed growth. The color of this mulch can be blue-green or brown (LAMONT Jr, 1993). TABER (1993) reported that the muskmelon yield from a wavelength-selective mulch in IOWA, USA, was comparable to transparent plastic, but its extra cost is not justified.

Among opaque mulches, highest tomato yield was obtained in white mulches (TABLE 3). PENDLETON et al. (1966) reported yield increases from 7 to $12 \%$ in corn plants growed in white plastic compared to unmulched soil, while black plastic resulted in small yield increase ( 3 to $5 \%$ ). ROBERTS \& ANDERSON (1994) reported that two out of 3 years, plots with a black plastic mulch had marketable yield lower than those from others treatments including opaque white plastic. The yield increases of crops due to white mulch have been attributed to an increasing of reflected solar radiation.

Economic questions also need to be addressed to determine if using black or white mulch in protected tomato crop in Southern Brazil. In this experiment did not have estatistical differences among mulch treatments. But the yield increase from the co-extruded white-on-black compared to black mulch was $12 \%$. This increase represented $115 \mathrm{~kg}$ of tomato fruits in a $250 \mathrm{~m}^{2}$ greenhouse. It is possible that the yield increase by white PE recompense it additional cost compared to the black PE.

The use of mulching with transparent plastic during crop growth is not expected in Southern Brazil. But, its use during the summer months for soil disinfestation (soil solarization) have a good potential (STRECK, 1994). It is recommended to paint the mulch after the solarization period. White is the color most recommended when transparent mulch will be transformed in opaque mulch.

\section{REFERENCES}

BRUNINI, O., SANTOS, J.M., ALFONSI, R.R., et al. Estudo micrometeorológico com cenouras (Variedade Nantes): I. Influência da temperatura do solo. Bragantia, v.35, n.4, p.49-54, 1976.

CLARKSON, V.A. Effect of black polyethylene mulch on soil and microclimate temperature and nitrate level. Agronomy Journal, v.52, n.6, p.307-9, 1960.
CLARKSON, V.A.; FRAZIER, W.A. Effect of paper and polyetylene mulches and plastic caps on cantaloupe yields and earliness. Proceedings of American Society for Horticultural Science, v.69, p.401-4, 1957.

DECICO, A. A determinação das propriedades térmicas do solo em condiçóes de campo. Piracicaba, 1974. 78p. Tese (Livre-Docência)-Escola Superior de Agricultura “Luiz đe Queiróz"/Universidade de São Paulo.

EKERN, P.C. Soil moisture and soil temperature changes with the use of black vapour-barrier mulch and their influence on pineapple (Ananas comosus (L.) Merr.) growth in Hawwai. Soil Science Society of America Proceedings, v.31, n.2, p.270-5, 1967.

EMMERT, E.M. Black polyethylene for mulching vegetables. Proceedings of American Society for Horticultural Science, v.69, p.464-8, 1957.

FARIAS-LARIOS, J.; GUZMAN, S.; MICHEL, A.C. Effect of plastic mulches on the growth and yield of cucumber in a tropical region. Biological Agriculture and Horticulture, v. 10, p. 303-6, 1994.

HAYNES, R.J. The use of polyethylene mulches to change soil microclimate as revealed by enzyme activity and biomass nitrogen, sulphur and phosphorus. Biology and Fertility of Soil, v.5, n.3, p.235-40, 1987.

LAMONT Jr., W.J. Plastic mulches for the production of vegetable crops. Hort Tecnology, v.3, n.1, p.35-9, 1993.

LIAKATAS, A.; CLARK, J.A.; MONTEITH, J.L. Measurements of the heat balance under plastic mulches. Agricultural and Forest Meteomlogy, v.36, p.227$39,1986$.

MULLINS, C.A.; STRAW, R.A.; RUTLEDGE, A.D. Tomato production with fertigation and black plastic mulch. Tennessee Farm and Home Science, p.23-8, 1992.

PENDLETON, J.W.; PETERS, D.B.; PEEK, J.W. Role of reflected light in the corn ecosystems. Agronomy Journal, v.58, p.73-4, 1966.

REY, Y.; COSTES, C. La phisiologie de la tomate: ftude bibliographique. Versailles: Institut National de la Recherche Agronomique/ Station Centrale de Phisiologie Végétale, 1965. 111 p.

ROBERTS, B.W.; ANDERSON, J.A. Canopy shade and soil mulch affect yield and solar injury of bell pepper. HortScience, v.29, n.4, p.258-60, 1994. 
ROSENBERG, N.J. Micnoclimate: the biological environment. New York: John Wiley, 1974. 315p.

SALMAN, S.R.; BAKRY, M.O.; ABOU, A.F., et al. The effect of plastic mulch on the microclimate of plastic greenhouse. Acta Horticulturae, n.287, p.471-425, 1990.

SCHNEIDER, F.M. Comportamento e propriedades térmicas do solo Santa Maria. Piracicaba, 1979.77p. Dissertação (Mestrado) Escola Superior de Agricultura "Luiz de Queiróz"/Universidade de São Paulo.

SCHNEIDER, F.M.; BURIOL, G.A.; ANDRIOLO, J.L., et al. Modificação na temperatura do solo causada por estufas de polietileno de transparente de baixa densidade em Santa Maria, RS. Revista Brasileira de Agrometeorologia, v.1, p.37-42, 1993.

STRECK, N.A. Modificação na temperatura do solo causada pela solarização em estufa plástica. Santa Maria, 1994. 82p. Dissertação (Mestrado)Universidade Federal de Santa Maria.
STRECK, N.A.; SCHNEIDER, F.M.; BURIOL, G.A. Modificações físicas causadas pelo mulching. Revista Brasileira de Agrometeorologia, v.2, p.131-42, 1994.

TABER, H.G. Early muskmelon production with wavelength-selective and clear plastic mulches. Hort Tecnology, v. 3, n. 1, p. 78-80, 1993.

TAKATORI, F.H., LIPPERT, L.F, WHITING, F.L. The effect of petroleum mulch and polyethylene films on soil temperature and plant growth. Proceedings of American Society for Horticultural Science, v.85, p.532-40, 1964.

VANDENBERG, J.; TIESSEN, $\mathbf{H}$. Influence of wax-coated and polyethylene-coated paper mulch on growth and flowering of tomato. HortScience, v.7, n.5, p. 46465,1972 .

Recebido para publicação em 26.06.95

Aceito para publicação em 25.08.95 